\title{
Investors boost Canadian startups but public sector underperforms
}

Big pharma invested heavily in Canadian biotech ventures in the first half of 2012. In May, Eli Lilly of Indianapolis said it would pump $\$ 40$ million into a Montreal venture fund focused on singleproject life sciences companies; and Londonbased GlaxoSmithKline (GSK) announced it would partner with Canada's Centre for Drug Research and Development (CDRD) to set up an innovation fund for early-stage projects. Earlier in the year, Merck of Whitehouse Station, New Jersey, also announced a \$35-million investment fund with Lumira Capital in

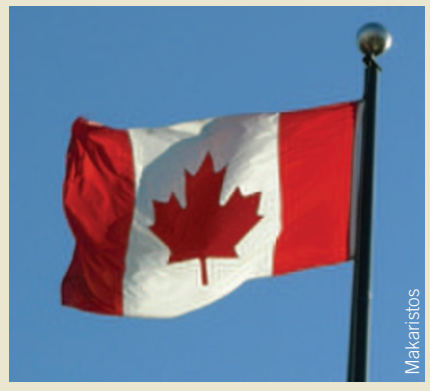
Toronto backing life sciences innovation in Québec (Nat. Biotechnol. 30, 395-400, 2012). The deals suggest that, despite plummeting revenues and R\&D expenditures, big pharma sees untapped potential in the translational science coming out of Canada.

These deals in startups contrast starkly with the grim numbers for Canadian public biotech companies as a whole. Revenues in 2011 from Canada's public biotech sector plummeted $21 \%$ and R\&D expenditures declined $4 \%$ from the prior year, according to Ernst \& Young's annual biotech report Beyond Borders, published in June. Meanwhile, public biotechs in the US and Europe saw a 9\% increase in R\&D and double-digit revenue growth (Table 1).

"The problem in Canada is that there is good science there, but it has been underfunded," says Jens Eckstein, president of SR One, GSK's venture arm. "It's the perfect scenario to start investing again. Valuations are down and it's the old school thinking: you want to be in places of scarcity."

Lilly's \$40-million investment is part of a \$150-million fund through Montreal-based TVM Capital that includes a $\$ 65$-million contribution from Teralys Capital, also in Montreal. The fund is aimed at early-stage companies working on a single project or therapeutic asset. Lilly will establish in Montreal a unit of Chorus, the company's autonomous early-phase drug development network, to help startups design lean development plans. Chorus' small staff will draw on expertise from Lilly and external consultants.

The GSK deal provides funding for early-stage projects conducted at CDRD, a not-for-profit drug development and commercialization center in Vancouver that works in collaboration with academic and other external investigators. A joint committee will select the projects to be supported from this fund. The deal also establishes a second fund in collaboration with CDRD's for-profit venture arm to advance projects toward commercialization. The partnership gives GSK an early, low-risk look at prevalidated projects, and the option to co-develop a

Table 1 Established biotech clusters at a glance project at any point in the collaborative process, says Karimah Es Sabar, Canada US Europe Australia

\begin{tabular}{lcccc}
\hline $\begin{array}{l}2011 \text { revenues (change } \\
\text { from 2010) }\end{array}$ & $-21 \%$ & $+12 \%$ & $+10 \%$ & $+6 \%$ \\
\hline $\begin{array}{l}2011 \text { R\&D expenditures } \\
\text { (change from 2010) }\end{array}$ & $-4 \%$ & $+9 \%$ & $+9 \%$ & $+13 \%$ \\
\hline \begin{tabular}{l} 
Number of public companies \\
\hline
\end{tabular} & 71 & 318 & 167 & 61 \\
\hline
\end{tabular}
president and CEO of CDRD. GlaxoSmithKline's financial commitment to the deal was not disclosed.

Government-backed

Source: Public company data and Ernst \& Young 2012 Beyond Borders report incentives and funds in Canada over the past few years may have helped draw big pharma, says Paul Karamanoukian, Ernst \& Young's Canadian life sciences leader in Montreal. Both the federal and provincial governments have been infusing public money into quasi-governmental investment groups, including Montrealbased Business Development Bank of Canada and Teralys Capital, and tagging part of those funds for life sciences. And notably, the Canadian government in March 2010 simplified a way for foreign investors to meet the exemption from a hefty tax-typically $25 \%$ - on the gain from the sale of their investment in a Canadian company. "We didn't see the impact of that immediately, but we're starting to see more foreign investment now," Karamanoukian says.

In fact, Canada's public biotech companies in 2011 raised \$574 million, a \$178-million increase over 2010. Considering the small number of public biotech companies in Canada, these figures may be better indicators of the health of the country's biotech industry than revenues and R\&D expenditures, says Glen Giovannetti, global life sciences leader at Ernst \& Young. However, the sector is still below financing levels of 2005, 2006 and 2007.

Emily Waltz Nashville, Tennessee 